\title{
Title: A study on the effect of vidangadi compound on lipid profile and
}

\section{fasting blood sugar}

\author{
Authors: Perera M.S.S* ${ }^{1}$ Samarakoon S.M.S ${ }^{2}$
}

1. $2^{\text {nd }}$ year M.S. scholar, department of Prasuti tantra and Stree Roga, IPGT\&RA, Gujarat Ayurved University, Jamnagar.

2. Senior Lecturer, Department of Deshiyachikitsa, Institute of Indigenous Medicine, University of Colombo, Sri Lanka.

*Corresponding Author: Email: pereisurangi@gmail.com, Mobile: 8140708185

\section{Abstract:}

Sthaulya is included under eight undesirable conditions (Ashtau Nindita), Shleshma Nanatmaa, Samtarpana Nimittaja, Atinindita, Ati Brihmana Nimittaja, and Bahu Dosha Janita Vikara. Moreover, Sushruta has emphasized on metabolic disturbances (Dhatva agnimandya) in the etiopathogenesis of Sthatisy. The World Health Organization (WHO) defines BMI between $25-29.9$ is overweight and BMI greater than 30 is obesity. The present study is a clinical study to evaluate the efficacy of Vidangadi Compound (VC) on Obesity and type II diabetes. Diagnosed patients were selected from Ayurveda Teaching Hospital at Borella from the period of January 2015 to May 2016. Thirty patients (30) who had BMI between 25 to 45 and fasting blood glucose $<200 \mathrm{mg} / \mathrm{dl}$ were included in the study. Subjective assessment criteria were the sympoms of obesity with proper grading whereas objective criteria were BMI, body circumferences, skin-fold thickness, Lipid profile and FBS. Data were analyzed by using SPSS statistical software. In this study, Vidangadi Compound (VC) in the form of pill was given $1 \mathrm{~g}$ (each pill 500mg) at 8.00 A.M \& 6.00 P.M before meal for eight weeks with $5 \mathrm{ml}$ bee honey. VC improved Sphik Chalata, Anga Gaurava, Anga daurgandaya, Ati- kshudha, Daurbalya, Sewedadikya, Uthsha hani, Gathrasada, Udara Chalata, Sthana Chalata, body circumferences, BMI, Skin Fold Thickness, Fasting Blood Sugar (from $96.30 \pm 1.63$ to $92.61 \pm 1.58$ ), Triglyceride (from126.94 \pm 8.28 to $115.84 \pm 9.02$ ) and HDL(from $46.88 \pm 1.98$ to52.13 \pm 1.01 ) in statistically highly significant manner ( $\mathrm{p}<0.001)$. VC is composed of Katu (66.6\%), Tikta (50\%) and Kashaya rasa (83.33\%); Laghu (33.33\%), Ruksha (33.3\%), Thiksna (16.66\%), Sukshma (16.6\%) and yogavahi guna ( $16.6 \%)$; Ushana virya (50\%) and Katu vipaka (83.3\%). Collectively, these properties of $\mathrm{VC}$ are responsible in improving subjective as well as objective parameters of sthaulya especially Lipid profile and Fasting Blood Sugar significantly.

Keyword: Vidangadi Compound, Obesity, Type-II Diabetes, Lipid profile, Fasting Blood sugar 


\section{Introduction:}

Sthaulya is included under Ashtaunindita purusha and diseases of Shleshma nanatmajai, Samtarpana nimittaja ${ }^{\mathrm{iii}}$, AtiBrihmana nimittaja, ${ }^{\text {iv }}$ and Bahudoshaja nitavikara ${ }^{\mathrm{v}}$.Accumulation of fat over the limit led to ill effect in the body known as obesity. Body mass index (BMI) is an index of weight-for-height that is commonly used to classify overweight and obesity. The World Health Organization (WHO) definition is ${ }^{\mathrm{vi}}$ a BMI greater than 25 is overweight and ${ }^{\text {vii }}$ BMI greater than 30 is obesity. Obesity and overweight occurs due to imbalance between calories consumed and calories utilized. Globally, there have been two reasons for overweight and obesity: ${ }^{7}$ an increased intake of energy-dense foods that are high in fat, salt and sugars; and $^{8}$ a decrease in physical activity due to the increasingly sedentary nature of many forms of wor and increasing urbanization. Overweigh and obesity are the fifth leading risk for global deaths. At least, 2.8 million adults die each year as a result of being overweight or obese. In addition, $44 \%$ of the diabetes burden, $23 \%$ of the ischemic heart disease burden and between $7 \%$ and $41 \%$ of certain cancer burdens are attributable to overweight and obesity. Overall, more than one in ten of the world's adult population is obese. viii In addition to increased future risks, obese persons experience breathing difficulties, increased risk of fractures, hypertension, cardiovascular diseases and psychological effects. ${ }^{\text {ix }}$

Apathyanimittaja prameha is caused by unhealthy dietary and lifestyle factors and it is well correlated with type II Diabetes Mellitus. Ayurveda possesses a number of valuable remedies that can be used in the management of apathyanimittaja prameha.

\section{JUSTIFICATION}

Obesity is one of the burning problems globally as it hamper the different systems in the body. An obese person is prone to land up in complications like dyslipidemia, hypertension, coronary heart diseases, diabetes mellitus, osteoarthritis, infertility, impotency and many psychological. Ayurveda is one of the highly developed indigenous systems of medicine in the world. The classical Vidangadi Compound had not been subjected to any scientific study to evaluate its efficacy on Sthoulya and apathyanimittaja prameha.

\section{Aims_and_Objects:}

his study was carried out to evaluate the efficacy of Vidangadi Compound on Sthoulya and apathyanimittaja prameha.

\section{METHODOLOGY}

The present study is a clinical study in which patients who fulfilled the criteria were selected from Ayurveda Teaching Hospital at Borella, Colombo 08, Sri Lanka from period of January 2015 to May 2016.Both male and female patients, between 20 -60 years of age, who had BMI between 25 to $45 \mathrm{~kg} / \mathrm{m}^{2}$ and FBS less than $200 \mathrm{mg} / \mathrm{dl}$ were included in the study. Sixty (30) patients were treated with Vidangadi Compound at the dose $1 \mathrm{~g}$ (each pill of $500 \mathrm{mg}$ ) 8.00 a.m \& 6.00 p.m before meal with $5 \mathrm{ml}$ bee honey for a period of eight (08) weeks.

Patients were evaluated before starting the treatment and after completing the 
treatment for their subjective as well as objective criteria. Subjective criteria (symptoms of sthaulya and apatyanimittaja prameha) were assessed with proper grading according to their severity. Objective assessment criteria were BMI, body circumferences, skin-fold thickness, lipid profile and FBS. ${ }^{x}$ Specific diet was recommended to each patient during the period of treatment.

Data were analyzed by SPSS statistical software. Qualitative data were analyzed by Wilcoxon Sign Rank test and MannWhitney test whereas quantitative data were analyzed by paired and unpaired students ' $t$ ' tests.

\section{Results and Observations:}

Majority of patients were in 40-49 age group (48.33\%), female (93.33\%), marrie (93.3\%), housewife (76.7\%), has secondary education $(78.3 \%)$, belonged to middle socio-economic status (86.7\%), and lived in suburban areas (66.7\%). Considering the family history, obesity and type II DM were among sisters (41.7\%), mother (38.3\%) and father $(30.0 \%)$.
The majority of patents had mixed diet (90\%); adayasana (53.3\%), vishamasana (36.7\%) and virudhasana (25\%); food rich in snigdha (73.3\%) and guruguna (70.0\%); madhurarasa (58.3\%); and visamagni (53.3\%). Considering the life style, the majority of patients had no exercise (68.3\%), had excessive sleep (61.7\%) and day sleep (36.7\%). Vata-kaphaprakriti (58.3\%) were more common among sthaulya and apatyanimittaja prameha. All most all patients had avara state of abayavarana shakthi and avara jarana shakthi (each 100\%).

\section{Effect of Vidangadi Compound on} Sthaulya and Apathyanimittaja prameha

The improvement of the mean value of Sphik Chalata (from 3.71 to 2.36), Anga

Gaurava (from 3.48 to 1.93) Anga daurgandaya (from 3.63 to 1.83 ),), AtiAshudha (from 2.00 to 0.14), Daurbalya ( from 3.42 to 1.53), Sewedaabadha ( from 3.38 to 1.67 ), Uthsha hani( from 3.19 to 1.85), Gathrasada ( from 3.54 to 1.85 ), Udara Chalata (from 3.69 to 1.93 ) and Sthana Chalata ( from 3.64 to2.14) was statistically highly significant $(\mathrm{p}<0.001)$. Ati- Trisha (from 3.64 to 1.43), Shuwasa (from 3.07 to 1.71) and Nidradikya (from 3.60 to 2.30 ) was statistically significant. $(\mathrm{p}<0.05)$.

Table 1: Effect of Vidangadi Compound on Body circumferences

\begin{tabular}{|c|c|c|c|c|c|c|}
\hline \multirow{2}{*}{ Parameter } & \multicolumn{2}{|l|}{ Mean } & \multicolumn{2}{|l|}{$\mathrm{SD} \pm \mathrm{SE}$} & \multirow{2}{*}{$\mathrm{t}$} & \multirow{2}{*}{$\mathrm{P}$} \\
\hline & BT & AT & BT & AT & & \\
\hline Mid Arm Circumference & 34.67 & 29.67 & $2.91 \pm 0.53$ & $5.91 \pm 1.08$ & 4.687 & $\mathrm{P}<0.001$ \\
\hline Waist Circumference & 106.03 & 97.93 & $7.88 \pm 1.44$ & $7.66 \pm 1.39$ & 16.565 & $\mathrm{P}<0.001$ \\
\hline Hip Circumference & 112.39 & 99.66 & $7.40 \pm 1.35$ & $18.50 \pm 3.37$ & 3.871 & $\mathrm{P}<0.001$ \\
\hline
\end{tabular}

The mean value of mid Arm Circumference, Waist Circumference and Hip Circumference, was reduced from 34.67 to 29.67 , from 106.03 to 97.93 , from 112.39 to 99.66 respectively. 
Therefore, mid Arm Circumference, Waist Circumference and Hip Circumference were statistically highly significant. $(\mathrm{p}<0.001)$.

\section{Table: Effect of Vidangadi Compound on BMI}

\begin{tabular}{|l|l|l|l|l|l|l|}
\hline \multirow{2}{*}{ Parameter } & \multicolumn{2}{|l|}{ Mean } & \multicolumn{2}{l|}{ SD \pm SE } & \multirow{2}{*}{ T } & \multirow{2}{*}{ P } \\
\cline { 2 - 5 } & BT & AT & BT & AT & & \\
\hline BMI & 36.54 & 31.77 & $3.99 \pm 0.73$ & $3.55 \pm 0.64$ & 18.55 & $\mathrm{P}<0.001$ \\
\hline
\end{tabular}

The mean value of BMI was reduced from 36.54 to 31.77 which is statistically highly significant $(\mathrm{p}<0.001)$.

Table 3: Effect of Vidangadi Compound on Skin Fold Thickness

\begin{tabular}{|c|c|c|c|c|c|c|}
\hline \multirow{2}{*}{ Parameter } & \multicolumn{2}{|l|}{ Mean } & \multicolumn{2}{|l|}{$\mathrm{SD} \pm \mathrm{SE}$} & \multirow{2}{*}{$\mathrm{T}$} & \multirow{2}{*}{$\mathrm{P}$} \\
\hline & BT & AT & BT & AT & & \\
\hline Bicep & 23.50 & 18.87 & $6.67 \pm 1.21$ & $6.58 \pm 1.20$ & 8.492 & $\mathrm{P}<0.001$ \\
\hline Triceps & 25.73 & 19.00 & $6.61 \pm 1.20$ & $4.66 \pm 0.85$ & 8.564 & $\mathrm{P}<0.001$ \\
\hline Supra iliac & 42.83 & 38.67 & & $5.93 \pm 1.08$ & 8.398 & $\mathrm{P}<0.001$ \\
\hline Mid thigh & 42.71 & 38.17 & 0.64 & $4.97 \pm 0.90$ & 6.561 & $\mathrm{P}<0.001$ \\
\hline Umbilical & 41.80 & 36.50 & $3.82 \pm 0.69$ & $5.36 \pm 0.97$ & 7.737 & $\mathrm{P}<0.001$ \\
\hline
\end{tabular}

The mean value of Skin Fold Thickness, middle portion of the Bicep (from 23.5 to 18.87), Triceps (from 25.73 to 19.00), Supra iliac (from 42.83 to 38.67 ), Mid- thigh (from 42.71 to 38.17 ) and Umbilical (from 41.80 to 36.50 ) was reduced in statistically highly significant manner. ( $\mathrm{p}<$ 0.001).

Table 4: Effect of Vidangadi Compound on Lipid profile and Fasting blood sugar

\begin{tabular}{|c|c|c|c|c|c|c|}
\hline \multirow{2}{*}{ Parameter } & \multicolumn{2}{|l|}{ Mean } & \multicolumn{2}{|l|}{$\mathrm{SD} \pm \mathrm{SE}$} & \multirow{2}{*}{$\mathrm{T}$} & \multirow{2}{*}{$\mathrm{P}$} \\
\hline & BT & AT & $\mathrm{BT}$ & AT & & \\
\hline $\begin{array}{l}\text { Total } \\
\text { Cholesterol }\end{array}$ & 193.52 & 191.44 & $\begin{array}{l}42.73 \pm \\
7.80\end{array}$ & $\begin{array}{ll}37.26 & \pm \\
6.80 & \end{array}$ & 0.423 & $p>0.05$ \\
\hline Triglyceride & 126.94 & 115.84 & $45.38 \pm 8.28$ & $49.40 \pm 9.02$ & 2.487 & $\mathrm{p}<0.05$ \\
\hline LDL & 119.60 & 118.93 & $45.73 \pm 8.34$ & $36.49 \pm 6.66$ & 0.151 & $p>0.05$ \\
\hline HDL & 46.88 & 52.13 & $10.87 \pm 1.98$ & $5.53 \pm 1.01$ & -3.167 & $\mathrm{p}<0.05$ \\
\hline FBS & 96.30 & 92.61 & $8.97 \pm 1.63$ & $8.66 \pm 1.58$ & 6.223 & $\mathrm{P}<0.001$ \\
\hline
\end{tabular}


The mean value of Fasting blood sugar (from 96.30 to 92.61) was reduced in statistically highly significant manner $(\mathrm{P}<0.001)$ whereas the mean value of Triglyceride (from 126.94 to 115.84) and HDL (from 46.88 to 52.13) was reduced statistically significant $\quad(\mathrm{p}<0.05)$. According to the reduction of mean value of total cholesterol (from 193.53 to 191.4) and LDL (from119.6 to 118. 93) was insignificant. ( $p>0.05)$.

\section{Discussions:}

In this study, collectively, $80 \%$ of patients belong to the age group of 30-49 meaning young adults and middle-aged people are more prone to have obesity. The majority of sthaulya patients are female (93.33\%). According to a study conducted by AI-Isa AN- Prevalence of obesity among adult Kuwaitis: a cross-sectional study, it ha been reported that obesity $(\mathrm{BMI} \geq 30.0)$ at present, estimated to be about $40.6 \%$ in adult females are obese. ${ }^{\mathrm{xi}}$ Hence, it is evident that females are more vulnerable to develop obesity. The majority of patients are married $(93.3 \%)$, housewives (76.7\%), having secondary education (78.3\%), belonging to middle socioeconomic status $(86.7 \%)$ and living in suburban areas $(66.7 \%)$. The majority of the patients are having gradual onset (98.3\%). Considering the family history, obesity is common among sisters (41.7\%) and mothers (38.3\%).

Considering the psychological history, this study reports that majority of the obesity patient having tension (45\%) which may be due to the effect of disease. Among female patients, the majority of patients are having regular menstrual cycle $(53.6 \%)$. The majority of patents are having mixed diet $(90 \%)$ than the people who take vegetarian diet (10\%). Excessive consumption of animal products rich in fat and oil is well established risk factor of obesity.

In this study, Vidangadi compound (VC) was given for a period of eight weeks $1 \mathrm{~g}$ ( 2 pills) twice a day, before meal with $5 \mathrm{ml}$ Bee honey. The improvement of Sphik Chalata, Anga Gaurava, Anga daurgandaya, Ati- kshudha, Daurbalya, Sewedaabadha, Uthsha hani, Gathrasada, Udara Chalata and Sthana Chalata is statistically highly significant $(\mathrm{p}<0.001)$ whereas Ati- Trisha, Shuwasa and Nidradikya is improved in statistically significant manner $(\mathrm{p}<0.05)$.

\section{Discussion on the effect of Vidangadi} compound

idangadi compound improved Sphik Chalata, Anga Gaurava, Anga daurgandaya, Ati- kshudha, Daurbalya, Sewedaabadha, Uthsha hani, Gathrasada, Udara Chalata and Sthana Chalata, Mid Arm Circumference, Waist Circumference, Hip Circumference, BMI, Skin Fold Thickness over middle portion of the Biceps, Triceps, supra iliac, Mid-thigh and Umbilical region Triglyceride, HDL, and Fasting Blood Sugar is statistically highly significant $(\mathrm{p}<0.001)$.

Vadangadi compound is composed of Katu rasa $(66.6 \%)$, Tikta rasa $(50 \%)$ and Kashaya rasa (83.33\%); Laghu guna (33.33\%), Ruksha guna (33.3\%), Thiksna guna (16.66\%), Sukshma guna (16.6\%) and yogavahi guna (16.6\%); Ushana virya (50\%) and Sheeta virya (50\%) and Katu vipaka (83.3\%). Vidanga is having kapha vata shamaka deepana, pachana, 
muthrakaraka, rakthasodaka and shothaharai properties. Nagara is composed of vata kapha shamaka, thrupthigna, deepana, trishna nigrahana and pachana properties. It is an appetizer and improves digestion. Yava is having thrusnahara property. Amalaki contains thridosagna, medya, daha prasamana, muthrakaraka, agnideepana, pachana, anulomana and rochana properties. Yavakshara is having kapha vata shamaka and agni deepana properties. Lahua bashma is having kapha and pitta shamaka, vayasthapana, and meda-hara effects. ${ }^{\text {xii }}$ Makshika (bee honey) contains thridosagna, kapha pitta shamaka, yogavahi, anti- inflammatory and anti oxidant properties. Collectively, these properties of VC are responsible in improving subjective as well as objective parameters of sthaulya significantly.

\section{Conclusion:}

By fore going, it may be concluded that Vadangadi compound is effective in improving most of the subjective as well as objective parameters of obesity (Sthaulya) and apathyanimittaja prameha. Finally, it may be suggested that these findings need to be validated by further research having more number of patients with longer duration of treatment.

\section{References:}

${ }^{\mathrm{i}}$ CharakaSamhita of Agnivesha

ChaukambhaOrientalia, Varanasi (Ch.

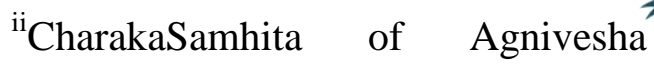

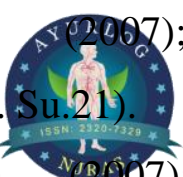

Translated by Sharma P.V,

ChaukambhaOrientalia, Varanasi Ch.Su. 20).

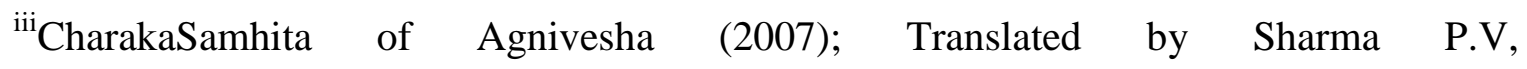

ChaukambhaOrientalia, Varanasi (Ch.Su. 23).

${ }^{\text {iv }}$ CharakaSamhita of Agnivesha (2007); Translated by Sharma P.V,

ChaukambhaOrientalia, Varanasi (Ch.Su.22).

${ }^{\mathrm{v}}$ CharakaSamhita of Agnivesha (2007); Translated by Sharma P.V,

ChaukambhaOrientalia, Varanasi (Ch.Su.16).

${ }^{\mathrm{vi}}$ World Health Organization, "Obesity. Preventing and managing the Global Epidemic, Report of a WHO consultation (WHO Technical Report Series 894), WHO, 2000. http://www. who.int/nutrition/publications/obesity/WHO_TRS_894/en/

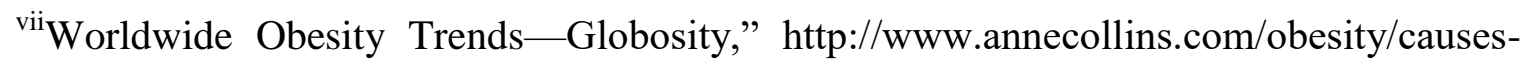
of-obesity.htm.

viii Obesity and overweight-Fact sheet No. 311, 2012. http:// www.who. int/media centre/factsheets/fs311/en/index.html 
${ }^{\text {ix }}$ Centre for Public Health Excellence at NICE (UK), National Collaborating Centre for Primary Care (UK), “Obesity: The Prevention, Identification, Assessment and Management of Overweight and Obesity in Adults and Children," National Institute for Health and Clinical Excellence (UK) (NICE Clinical Guidelines, No.43), 2006. http:// www.ncbi.nlm.nih.gov/books/ NBK 63696).

${ }^{\mathrm{x}}$ An International Quarterly Journal of Research in Ayurveda /AYU 2014 Jan-Mar; 35(1): 28-34 Shri Kant Tiwari Department of Kaya Chikitsa, Faculty of Ayurveda, Institute of Medical Sciences, Banaras Hindu University, Varanasi, India).

${ }^{x i}$ AI-Isa AN. Prevalence of obesity among adult Kuwaitis: a cross-sectional study. Int. J. Obese, 1995; 19:431-433.

\section{Cite article:}

A study on the effect of vidangadi compound on lipid profile and fasting blood sugar Perera M.S.S, Samarakoon S.M.S

Ayurlog: National Journal of Research in Ayurved Science- 2018; (6)(4): 1-7 